\title{
Özel Yetenekli Öğrencilerin Okul Yönetim Algısı
}

\author{
ECE BERIL ALTIN \\ MERT TURGUT TOPRAK \\ NEHIR KORKMAZ
}

Özet

21. yüzyıldaki gelişmeler birçok alanda olduğu gibi eğitim alanında da etkili olmuş ve birtakım değişikliklere sebebiyet vermiştir. Yeni bir eğitim politikası olarak 2023 Eğitim Vizyonu belgesi de bu değişim çerçevesinde yapılandırılmış ve Türk Eğitim sisteminde yerini alarak gelişmelere cevap vermeye çalışmıştır. Bu vizyon çerçevesinde Türkiye, eğitimde yenilikler yaparak ezberci eğitimden uzak, dünyadaki gelişmelere ayak uydurmaya çalışan 21. yy. becerilerine sahip sorumluluk bilinci edinmiş üretken bireyler yetiştirmeyi amaçlamaktadır. 21. yy. becerileriyle donanmış nitelikli insan aynı zamanda bir ülkenin potansiyel güç kaynağını oluşturmaktadır ki bu gücü oluşturan kaynaklardan biri genç nüfustur. Özel yetenekli öğrenciler de bu genç nüfusun önemli bir bölümünü oluşturmaktadır. Ülkelerin ve toplumun en büyük zenginliği olarak görülen ve literatürde "armağan çocuklar" ve "yer altı cevheri" olarak tanımlanan özel yetenekli öğrenciler, nitelikli insan gücünü oluşturmaları münasebetiyle

- ARASTIRMA MAKALESI-

ECE BERIL ALTIN, ebaltin32@gmail.com Elazığ Bilim ve Sanat Merkezi, Ögrrenci ORCID: https://orcid.org/0000-0001-7444-6548

MERT TURGUT TOPRAK, merttrgt23@gmail.com Elazığ Bilim ve Sanat Merkezi, Ögrenci ORCID: https://orcid.org/0000-0001-9730-7698

NEHIR KORKMAZ, nehirkorkmaz@yandex.com Elazığ Bilim ve Sanat Merkezi, Öğrenci ORCID: https://orcid.org/0000-0002-6473-3508

Gelis Tarihi 25.09.2020 • Kabul Tarihi 06.11.2020 doi: https://doi.org/10.47646/CMD.2020.194 
devletler için stratejik öneme sahip güç unsuru olmuştur. Bütün devletler insan kaynaklarını verimli kullanmak adına nitelikli ve özel yetenekli insan gücüne ulaşmaya çalışmış ve bu potansiyeli ülke yararına kullanmak istemiştir. Devletler kendilerini korumak, güçlü hissetmek ve devamlılıklarını sürdürmek için özel yetenekli bireyleri devlet hizmetinde kullanarak bu potansiyelden yararlanmışlardır. Bu yüzyıldaki gelişmeler aynı zamanda öğrenci ve velilerin, okul ve müdürlerden beklentilerinin değişmesine de neden olmuştur. Dünyada meydana gelen değişime bağlı olarak okul müdürlerinin de kendilerini bu değişim ve dönüşüme göre yeniden konumlandırması, değişerek ve dönüşerek daha güçlü ve esnek bir yapıya bürünmeleri gerekmektedir. Bu çalışmada özel yetenekli öğrencilerin okul yönetimine dair düşüncelerini açı̆̆a çıkarmak amaçlanmıştır. Özel yetenekli öğrencilerin okul yönetimine dair düşüncelerinin bilinmesi, hem özel yeteneklilerin eğitiminde etkili olan faktörlerin hem de özel yetenekli öğrencilerin eğitiminin daha iyi anlaşılmasını sağlayacaktır.

Anahtar kelimeler: Özel Yetenekli Öğrenci, Okul Yönetimi, Eğitim

\begin{abstract}
Developments in the 21st century have been effective in the field of education, as in many other fields, and have caused some changes. As a new education policy, the 2023 Education Vision document was structured within the framework of this change and tried to respond to the developments by taking its place in the Turkish Education system. Turkey in the framework of this vision, making innovations in education away from rote education, trying to keep pace with global developments responsibility 21 st century skills to individuals who have acquired productive aims to educate. Qualified people equipped with 21 st century skills also constitute a country's potential power source, one of which is the young population. Special talented students also constitute a significant part of this young population. Specially talented students, who are seen as the greatest wealth of countries and society and defined as "gift children" and "underground ore" in the literature, have become a strategically important power factor for states due to their creation of qualified manpower. All states tried to reach qualified and specially talented manpower in order to use human resources efficiently and wanted to use this potential for the benefit of the country. States have benefited from this potential by using talented individuals in government service in order to protect themselves, feel strong and maintain their continuity. Developments in this century have also caused changes in the expectations of students and parents from schools and principals. Depending on the change in the world, school principals need to reposition themselves according to this change and transformation, and adopt a more powerful and flexible structure by changing and transforming. In this study, it is aimed to reveal the thoughts of gifted students on school management. Knowing the thoughts of gifted students
\end{abstract}


on school management will provide a better understanding of both the factors affecting the education of special talented students and the education of gifted students.

Keywords: Gifted Student, School Management, Education

\section{Giriş}

21. yüzyıldaki gelişmelerden etkilenerek şekillenen alanlardan biri de eğitimdir. Bu yüzyıldaki gelişmeler eğitim uygulamalarını şekillendirmiş aynı zamanda eğitimden beklentileri değiştirmiştir. Böylece bireylerin kişisel ve mesleki becerileri ile sosyal değerlerini geliştirmelerine imkân verecek değişim ortaya çıkmıştır (Kesen, Sundaram ve Abaslı, 2019). Bu değişim karşısında Türkiye'nin gelişmesi, zamanın şartlarına uyum sağlayarak bunun devam ettirebilmesi eğitim alanındaki gücüne bağlıdır. Bu bağlamda 2023 Eğitim Vizyonu belgesi yeni bir eğitim politikası olarak Türk Eğitim sisteminde yerini almış ve gelişmelere cevap vermeye çalışmıştır. Bu vizyon çerçevesinde Türkiye, eğitimde yenilikler yaparak ezberci eğitimden uzak, dünyadaki gelişmelere ayak uydurmaya çalışan 21. yüzyıl becerilerine sahip sorumluluk bilinci edinmiş üretken bireyler yetiştirmeyi amaçlamaktadır.

21. yüzyıl becerileriyle donanmış nitelikli insan aynı zamanda bir ülkenin potansiyel güç kaynağını oluşturmaktadır ki bu gücü oluşturan kaynaklardan biri genç nüfustur. Özel yetenekli öğrenciler de bu genç nüfusun önemli bir bölümünü oluşturmaktadır. Ülkelerin ve toplumun en büyük zenginliği olarak görülen ve literatürde " armağan çocuklar" ve " yer üstü cevheri” olarak tanımlanan özel yetenekli öğrenciler, nitelikli insan gücünü oluşturmaları münasebetiyle devletler için stratejik öneme sahip güç unsuru olmuştur. Sahip oldukları potansiyel ve özellikler bakımından tarih boyunca devletlerin dikkatini çekmişlerdir. Devletler kendilerini korumak, güçlerini ve devamlılıklarını sürdürmek için özel yetenekli bireyleri devlet hizmetinde kullanarak bu potansiyelden yararlanmışlardır. Bütün devletler insan kaynaklarını verimli kullanmak adına nitelikli ve özel yetenekli insan gücüne ulaşmaya çalışmış ve bu potansiyeli ülke yararına kullanmak istemiştir.

Üstün yeteneklilik "normal kabul ettiğimiz standartlardan hem niteliksel hem niceliksel açıdan farklı içsel deneyimler ortaya koyan ve ileri zihinsel becerileri kapsayan eş zamanlı olmayan gelişim" diye tanımlanmıştır (Morelock 1992' den akt. Levent 2014, s.4). Üstün yeteneğin sayısal verilerle tanımlanmasının doğru olmadığı üstün yeteneğin bir sonuç değil süreç olduğu belirtilmekte ayrıca üstün yeteneklinin hayatın karmaşıklığını 
anlama kapasitesine sahip olduğu belirtilmektedir (Roeper 1995'ten akt. Levent 2014, s. 4). Ülkemizde ise üstün yetenekliler Bilim ve Sanat Merkezleri’nin (BILLSEM) yönergesine göre, “Özel yetenekli çocuk; özel akademik alanlarda veya zekâ, yaratıcılık, sanat ve liderlik kapasitesi yönüyle yaşıtlarına göre yüksek düzeyde performans gösteren ve bu tür yeteneklerini geliştirmek için okul tarafından sağlanamayan hizmet veya faaliyetlere gereksinim duyan bireydir" şeklinde tanımlanmaktadır (MEB, Bilsem Yönergesi, 2016).

Normal eğitim kurumları, üstün yetenekli öğrencilerin potansiyellerini geliştirmek için gerekli katkıyı sunamadıklarından bu çocukların eğitiminde yeterli olmamaktadır. Dolayısıyla üstün yetenekli öğrencilerin farklı eğitim programlarıyla desteklenmesi yetenek ve kapasitelerini geliştirmeleri için eğitim ihtiyaçlarının karşılanması gerekir. Bu anlamda Levent (2014, s.39) özel yetenekli öğrencilerin iki temel ihtiyacına dikkat çeker. Birinci ihtiyaçları kendilerini zorlayan ve motive eden etkinlikler, ikincisi de potansiyellerini geliştirmedir. Özel yetenekli öğrencilerin bu zorlayıcı etkinlikleri de kendi özgüvenlerini inşa etmek için kullanmak istedikleri bilinmektedir (Kahveci, 2015 s.50). Özel yeteneklilerin erken yaşta yönlendirilmeleri gelişimlerini hızlandırmakta ve topluma katkı sunan bireyler olmalarını sağlamaktadır. Bunun yanında kendini gerçekleştirme ve üretme firsatı verilmeyip gerekli yönlendirme ve eğitim ihtiyaçlarının karşılanmaması durumunda hem kendilerine hem de çevrelerine zarar verebilirler (Levent 2014, s.41). Zamanında fark edilmeyen ve ihtiyacı olan eğitimi alamayan üstün yetenekliler toplum için telafisi olmayan eksiklik olarak kalacaklardır (Enç, Çağlar ve Özsoy'dan akt. Levent 2014, s.41). Özellikleri ve yetenekleri doğrultusunda yönlendirildikleri ve değerlendirildikleri takdirde özel yetenekli öğrencilerin ülke gelişimine önemli katkı sundukları bilinmektedir.

Dünyadaki gelişmeler öğrencilerin eğitimden beklentilerini de değiştirmiştir (Aç1kgenç, Köse, Günel ve Demirkol, 2011'den akt. Acar, 2019 s.2). Öğrenci beklentilerinin değişmesine bağlı olarak velilerin ve toplumun da okuldan beklentileri değişmiştir. Okul başarısının düzenli bir şekilde artmasında ve okul kültürünün devamında etkili olan temel noktalardan biri de nitelikli okul yöneticilerdir. Beklentiler okul yönetimi ve müdürlerin performansını da kapsamaktadır. Bu bağlamda iletişim ve problem çözme becerileri yüksek, işbirliği yapabilen, yeniliklere açık ve vizyon sahibi olma gibi niteliklere sahip müdürlerin etkili bir yönetim sergileyecekleri düşünülmektedir (Ada ve Akan, 2007'den akt. Acar 2019, s.2). Dünyada meydana gelen değişime bağlı olarak okul müdürlerinin de kendilerini bu değişim ve dönüşüme göre yeniden konumlandırması, değişerek ve dönüşerek daha güçlü ve esnek bir yapıya bürünmeleri gerekmektedir 
(Kesen, Sundaram ve Abaslı, 2019). 21. yüzyılda okul yöneticilerinin teknolojiyi takip eden, iletişim ve problem çözme becerilerine sahip aynı zamanda kendini sürekli geliştiren kişilerden olması beklenmektedir. Tüm bu özellikler dikkate alındığında okul yönetim ve yöneticisinin eğitimde etkili olduğu görülmektedir. "Okul müdürleri okul yönetiminin en kritik ögeleri olarak kabul edilmektedir. Okulların etkili olması ve önceden belirlenmiş amaçlara ulaşabilmesi büyük ölçüde etkinliklerde, eğitim ve öğretim programının yürütülmesinden sorumlu yöneticilerin etkisine bağlıdır” (Kesen, Sundaram ve Abasl1, 2019).

Özel yetenekli öğrencilerin okul yönetimine dair düşüncelerinin bilinmesi, hem özel yeteneklilerin eğitiminde etkili olan faktörlerin hem de özel yetenekli öğrencilerin eğitiminin daha iyi anlaşılmasını sağlayacaktır. Bu çalışmada özel yetenekli öğrencilerin okul yönetimine dair düşüncelerini açığa çıkarmak amaçlanmıştır. Bu amaç doğrultusunda aşağıdaki beş alt probleme cevap aranmıştır.

1. Okul yönetimi ne demektir?

2. Okul yöneticisi okulu nasıl yönetmelidir?

3. Okul yönetiminin temel ilkeleri neler olmalıdır?

4. Okul yöneticisi öğretimi daha etkili hale getirmek için neler yapabilir?

5. Okul yöneticisi ders programlarını nasıl oluşturmalıdır?

\section{Yöntem}

\section{Araştırma Modeli}

Özel yetenekli öğrencilerin okul yönetimi algısını açığa çıkarmayı amaçlayan bu çalışma nitel bir araştırmadır. Nitel araştırma, gözlem, görüşme ve doküman analizi gibi nitel veri toplama yöntemlerinin kullanıldığı, algı ve olayların doğal ortamda gerçekçi ve bütüncül bir biçimde ortaya konulmasına yönelik nitel bir sürecin izlendiği araştırma olarak tanımlanmaktadır. Başka bir deyişle nitel araştırma, kuram oluşturmayı temel alan bir anlayış olarak sosyal olguları bağlı bulundukları çevre içerisinde araştırmayı ve anlamayı ön plana alan bir yaklaşımdır (Yıldırım ve Şimşek, 2013, s.45). Özel yetenekli öğrencilerin okul yönetim algısına ulaşmayı amaçlayan bu çalışmada görüşme yöntemi kullanılmıştır. Nitel araştırmalarda en çok kullanılan veri toplama yöntemi olan görüşme, insanların bakış açılarını, duygularını ve algılarını ortaya koymada kullanılan oldukça güçlü bir yöntemdir ( Bogdan ve Biklen,1992' den akt. Yıldırım ve Şimşek, 2013, s.47). 


\section{Çalışma grubu}

Bu araştırma, 2019-2020 eğitim-öğretim yılında (A) il merkezinde bulunan Bilim ve Sanat Merkezi'ne devam eden özel yetenekli 10. sınıf öğrencileriyle yapılmıştır. Araştırmanın katılımcıları, $7 \mathrm{kız}$ ve 7 erkek olmak üzere toplam 14 öğrenciden oluşmaktadır. Öğrenciler araştırmacı tarafından gizliliğin sağlanması amacıyla K1, K5 gibi kodlarla kodlanmıştır.

\section{Verilerin Toplanması ve Analizi}

Araştırmada, öğrencilerin okul yönetimi ve yöneticileriyle ilgili düşüncelerine ulaşmak için yarı yapılandırılmış görüşme formu kullanılmıştır. Araştırma verileri bu formdan elde edilmiş, veriler görüşme sürecinde telefon cihazı kullanılarak kayıt altına alınmıştır. Sonrasında ses kayıtları bilgisayar ortamında yazılı hale getirilmiştir. Katılımcılar, görüşme öncesi araştırma hakkında bilgilendirilmiş ve ses kaydı alınacağı belirtilmiştir. Araştırma verileri, Bilim ve Sanat Merkezi kütüphanesinde telefon cihazı kullanılarak kayıt altına alınmıştır.

Özel yetenekli öğrencilerin okul yönetim algısını ortaya çıkarmayı amaçlayan araştırmada, 15 açık uçlu sorudan oluşan bir "Görüşme Formu” kullanılmıştır. Araştırmada kullanılan 13 soru (Güneş, 2014)'ün ün yüksek lisans tezinden yararlanılarak oluşturulmuş ve kullanılmıştır. Görüşme formundaki 1., 2. ve 6. soru 1. alt problemin, 3., 4. ve 7. soru 2. alt problemin, 5., 11. ve 12. soru 3. alt problemin, 9. ve 13. soru 4. alt problemin, 8 . ve 10 . soru 5 . alt problemin ve 14 . ve 15 . sorular ise 6.alt problemin sorularidır.

Özel yetenekli öğrencilerin okul yönetim algısını açı̆̆a çıkarmak için yapılan bu araştırmada 13 soru sorulmuştur. Katılımcıların verdiği cevaplardan elde edilen verilerin analizinde nitel veri analiz yaklaşımlarından betimsel analiz kullanılmıştır. Betimsel analiz yaklaşımına göre elde edilen veriler, daha önceden belirlenen temalara göre özetlenir ve yorumlanır. Betimsel analizde, görüşülen ya da gözlenen bireylerin görüşlerini çarpıcı bir biçimde yansıtmak amacıyla doğrudan alıntılara sık sık yer verilir. Bu tür analizde amaç, elde edilen bulguları düzenlenmiş ve yorumlanmış bir biçimde okuyucuya sunmaktır. Bu amaçla elde edilen veriler, önce sistematik ve açık bir biçimde betimlenir. Daha sonra yapılan betimlemeler açıklanır ve yorumlanır, neden-sonuç ilişkileri irdelenir ve birtakım sonuçlara ulaşılır. Ortaya çıkan temaların ilişkilendirilmesi, anlamlandırılması ve ileriye yönelik tahminlerde bulunulması da, araştırmacının yapacağı yorumların boyutları arasında yer alabilir (Yıldırım ve Şimşek, 2013, s. 256). 


\section{Bulgular ve Yorum}

Özel yetenekli öğrencilere, verdikleri bilgiler arasındaki benzerliği veya farklılığı belirlemek amacıyla yarı yapılandırılmış 13 soru sorulmuştur. Bu 13 sorudan elde edilen bulgular beş alt problem içerisinde sunulmuştur.

\section{Birinci Alt Probleme İlişkin Bulgular}

Katılımcılara sorulan «Okul yönetimi sizce ne demektir " sorusuna ilişskin katılımcıların verdiği cevaplar Tablo 1'de sunulmuştur.

Tablo 1. Okul Yönetiminin Ne Olduğuna İlişkin Katılımcı Görüşleri

\begin{tabular}{ll}
\hline Görüşler & Katılımcı \\
\hline Disiplin sağlayıcı, & $\mathrm{K} 1$ \\
İhtiyaç karşılayıcı, & $\mathrm{K} 1, \mathrm{~K} 3, \mathrm{~K} 4$ \\
Denetleyici, & $\mathrm{K} 3$ \\
Okul bileşenlerinin birlikteliği, & $\mathrm{K} 2$ \\
Müdür ve müdür yardımcılarından oluşan ekip, & $\mathrm{K} 3, \mathrm{~K} 4, \mathrm{~K} 6$ \\
Davranış belirleyici, & $\mathrm{K} 6$ \\
\hline
\end{tabular}

Özel yetenekli öğrencilerin verdikleri cevaplar dikkate alındığında okul yönetimini genellikle «ihtiyaç karşılayan bir merci» olarak algıladıkları ve bu mercinin müdür ve müdür yardımcılarından oluştuğunu düşündükleri görülmektedir. «Disiplin sağlayıcı" ve «denetleyici» olarak da algılanan yönetimin ayrıca «davranış belirleme» hususunda karar verici olduğu da ifade edilmektedir. Katılımcıların "Okul yönetimi sizce ne demektir» sorusuna verdiği cevaplardan yapılan bazı alıntılar aşağıda sunulmuştur.

K1 “Okul yönetimi okulda öğrenciler ve öğretmenler arasında disiplini sağlayan okulun herhangi bir ihtiyacı olduğunda başvurulan ilk mercidir."

K3 "Müdür ve müdür yardımcılarından oluşan okulu denetleyen ve gerekli ihtiyaçlarını karşılayan ekip."

K6 "Okul yönetimi bence müdür ve müdür yardımcılarından oluşan topluluğun okulda öğrencilerin ve öğretmenlerin nasıl davranması gerektiğine karar vermesidir."

\section{İkinci Alt Probleme İlişkin Bulgular}

Katılımcılara sorulan "Okul yöneticisi olsanız okulu nasıl yönetirsiniz?» sorusuna ilişkin katılımcıların verdiği cevaplar Tablo 2'de sunulmuştur. 
Tablo 2. Okul Yöneticisi Olsalardı Okulu Nasıl Yöneteceklerine İlişkin Katılımcı Görüssleri

\begin{tabular}{ll}
\hline Görüşler & Katılımcı \\
\hline Öğrencilerin istek, öneri ve şikâyetlerine göre, & $\mathrm{K} 2, \mathrm{~K} 3, \mathrm{~K} 4, \mathrm{~K} 5, \mathrm{~K} 7, \mathrm{~K} 10$ \\
Resmiyet ve Disiplin temellinde, & $\mathrm{K} 1, \mathrm{~K} 3, \mathrm{~K} 4, \mathrm{~K} 5, \mathrm{~K} 8, \mathrm{~K} 9, \mathrm{~K} 11, \mathrm{~K} 13, \mathrm{~K} 14$ \\
Öğretmen odaklı & $\mathrm{K} 3, \mathrm{~K} 5, \mathrm{~K} 6$ \\
\hline
\end{tabular}

Özel yetenekli öğrencilerin okul yönetiminde, öğrencilerin istek ve görüşleriyle öğretmen ihtiyacını merkeze alan bir yönetim anlayışını benimsedikleri görülmektedir. Bunu gerçekleştirirken okuldaki öğretmen, öğrenci, veli ve çalışanları bir bütünlük ve ahenk içinde yönetmek istedikleri dikkat çekmektedir. K2 bu konuyu öğrencilerin ülke geleceğindeki etkisine dikkat çekerek açıklamakta ve öğrencilerin istek ve şikâyetlerinin dikkate alınmasını önemsediğini ifade etmektedir. K5 “...Onların önerilerini dinlemek isterdim” cümlesiyle yönetime öğrenci katılımını sağlamayı dolayısıyla öğrenci önerilerini dikkate alacağını ifade etmiştir. K3 de kendi okul yönetimini, öğrenci okul uyumundan kaynaklanan ahenge vurgu yapıp resmiyete dikkat çekerek açıklamıştır. Özel yetenekli öğrenciler okulu disiplin temelli bir yaklaşımla yöneteceklerini ifade etmiştir. Ayrıca öğrenciler, okuldaki tüm bileşenler arasında uyum ve ahengi sağlayan bir bakış açısıyla okulu yöneteceklerini belirtmişlerdir. Katılımcıların «Okul yöneticisi olsanız okulu nasıl yönetirsiniz?» sorusuna verdiği cevaplardan yapılan bazı alıntılar aşağıda sunulmuştur.

K2 “Genelde okul demek öğrenci yetiştirmek öğrenci ilerde ülkemizin yönetecek kişileri yetiştirmek demektir. O yetiştirilecek yerleridir. O yüzden onların nasıl yetiştirilmek istiyorlarsa öyle yetiştirilmesini sağlamaktır. Hani belirli olarak toplantılar yapıp sonra okuldaki sınıf şikâyetlerinin de, şikâyetler doğrultusunda yönetebilirdim öğrencilerin şikâyetleri doğrultusunda."

K6 “Okul yöneticisi olsaydım okulda öğrencilerin fikirlerinden ziyade öğretmenlerin fikirlerine daha çok önem verirdim."

K4 "Öğrencilerle ve velilerle aradaki mesafeyi korurdum ama katı da davranmazdım."

K11 "Okul yöneticisi olsam disiplini elden bırakmadan ama aynı zamanda öğrencilere de okulu sevdirerek her şeyi dengeli tutmaya çalışarak yönetirdim."

K13 "Disiplinli ama sıkıcı olmayacak şekilde." 


\section{Üçüncui Alt Probleme İliş̧in Bulgular}

Katılımcılara sorulan "Sizce okul yönetiminin temel ilkeleri nelerdir?» sorusuna ilişkin katılımcıların verdiği cevaplar Tablo 3'te sunulmuştur.

Tablo 3. Okul Yönetiminin Temel İlkelerinin Ne Olduğuna İlişkin Katılımcı Görüşleri

\begin{tabular}{ll}
\hline Görüşler & Katılımcı \\
\hline Sosyal ve iletişim becerileri, & $\mathrm{K} 3, \mathrm{~K} 4, \mathrm{~K} 5, \mathrm{~K} 6$ \\
Öğrenci motivasyonunu arttırmak, & $\mathrm{K} 2, \mathrm{~K} 3, \mathrm{~K} 5$ \\
Disiplin, & $\mathrm{K} 1, \mathrm{~K} 4, \mathrm{~K} 8, \mathrm{~K} 9, \mathrm{~K} 10, \mathrm{~K} 11, \mathrm{~K} 14$ \\
Kaliteli eğitim, & $\mathrm{K} 3, \mathrm{~K} 5$ \\
Öğretmen odaklı olma, & $\mathrm{K} 3, \mathrm{~K} 5, \mathrm{~K} 6$ \\
Güvenli ortam, Duygusal destekleme, & $\mathrm{K} 5, \mathrm{~K} 7$ \\
\hline
\end{tabular}

Özel yetenekli öğrencilerin okul yönetiminde dikkat çektiği ilkelerin disiplin, iletişim becerileri ve öğrenci motivasyonunu sağlamak olduğu görülmektedir. Öğrencilerin disiplin temelinde değerlere yer vermesi dikkat çekmektedir. Ayrıca öğretmenin işini sever hale getirmek için gerekli ortamın sağlanması ifade ettikleri bir başka yönetim ilkesidir. $\mathrm{K} 3$ “... müdürlerin ve müdür yardımcılarının kaba olmadan öğrencilerle beraber öğrencilerin isteklerini dinleyebilmeleri gerek" cümlesiyle idarecilerin iletişim becerilerine dikkat çekmiş ayrıca "İyi bir okul yönetiminin temel ilkeleri öğretmenlerin güzel bir ders anlatabilmeleri” cümlesinde de öğretmenlere vurgu yapmıştır. K5 güvenli eğitim ortamını, duygusal ihtiyaçların karşılanması bağlamında açıklayarak kaliteli eğitimin önemini "İkincisi o okulda bulunan insanların insanlara duygusal bir açıdan destek olabilmektir. Çünkü okul çok fazla zaman harcadığımız bir ve güvenli bir ortam olması gerektiğine inanıyorum. ...Yani temel ilke kaliteli bir eğitim vermek olmalıdır" diyerek ifade etmiştir. $\mathrm{K} 7$ güvenli eğitim ortamının kaliteli eğitimle bağlantısını "Eğitmeyi gerçekleştirebilecek doğrultuda hareket etmeleri. Eksikleri, okulun maddi olsun öğrencilerin mutluluğu olsun o yönden tamamlanabilecek şekilde olmasın isterdim. Öyle düşünüyorum" cümlesiyle açıklamıştır. $\mathrm{K} 6$ yönetimin sadece yönetimin öğretmenlerle samimiyet kurmasını ve hiyerarşinin korunmasını savunmuştur. K2 öğrenci odaklı olmayı önceleyerek okulda eğlenceli bir ortamın olması gerektiğini "Şimdi bir okulda öğrenciler okula geldiğinde sıkılmamalı bence bu yüzden okul eğlenceli bir hale getirilmeli" cümlesiyle dile getirmiştir. Yönetimin temel ilkelerini disiplin çerçevesinde değerlendiren K14 "Bence temel ilkeleri öğrencilere disiplin vermektir ve geleceklerinde başarı săglamalarında yardımcı olmaktı"” 
cümlesiyle belitmiş ayrıca bu yaklaşımın başarıyı beraberinde getireceğini ifade etmiştir. Yine K11 "Bence okul yönetiminin temel ilkesi disiplindir. Yeri gelir öğretmenler arkadaşımız öğrenciler çocuklarımız olur ama her zaman bir disiplin olması şarttır." cümlesiyle düşüncelerini ifade etmiştir. Katılımcıların «Sizce okul yönetiminin temel ilkeleri nelerdir?» sorusuna verdiği cevaplardan yapılan bazı alıntılar aşağıda sunulmuştur.

K3 “...ve müdürlerin ve müdür yardımcılarının kaba olmadan öğrencilerle beraber öğrencilerin isteklerini dinleyebilmeleri gerek."

K4 "Okulda disiplin sağlanmalı ama yani çok fazla söyledim katı da davranılmamalı."

K2 "Şikayetler doğrultusunda girdik konuya. Şimdi bir okulda öğrenciler okula geldiğinde sıkılmamalı bence bu yüzden okul eğlenceli bir hale getirilmeli. Bunu yapmak için de öğretmenlerin yardımı çok büyük. Mesela sokaklara yeni bir uygulamalar var mesela her sokağa bir dersin sokağı yapıyorlar. Öğrenciler mesela oradan yardım alıyorlar. Arkadaşlarıyla beraber inceleyip burada ne varmış falan diyorlar. Bence okulu eğlenceli hale getirmek için birçok yön var."

K1 "Okul yönetiminin temel ilkeleri başta da bahsettiğim gibi disiplindir..."

K4 "Okulda disiplin sağlanmalı..."

K5 “...İkincisi o okulda bulunan insanların insanlara duygusal bir açıdan destek olabilmesidir. Çünkü okul çok fazla zaman harcadığımız bir yer ve güvenli bir ortam olması gerektiğine inanıyorum. ...Yani temel ilke kaliteli bir eğitim vermek olmalıdır."

\section{Dördüncü Alt Probleme îliş̧kin Bulgular}

Katılımcılara sorulan "Okul yöneticisi öğretimi daha etkili hale getirmek için neler yapabilir?" sorusuna ilişkin katılımcıların verdiği cevaplar Tablo 4'te sunulmuştur.

Tablo 4. Okul Yöneticisinin Öğretimi Daha Etkili Hale Getirmek İçin Neler Yapabileceğine İlişkin Katılımcı Görüşleri

\begin{tabular}{ll}
\hline Görüşler & Katılımcı \\
\hline Teftiş, & $\mathrm{K} 1, \mathrm{~K} 6$ \\
Kaliteli eğitim ortamı, & $\mathrm{K} 3, \mathrm{~K} 11, \mathrm{~K} 12, \mathrm{~K} 13$ \\
Öğrenci görüşlerine göre & $\mathrm{K} 2, \mathrm{~K} 5$ \\
Eğlenceli uygulamalı ortam & $\mathrm{K} 2, \mathrm{~K} 4, \mathrm{~K} 8, \mathrm{~K} 9, \mathrm{~K} 14$ \\
Öğretmen görüşüne göre & $\mathrm{K} 7, \mathrm{~K} 10$ \\
\hline
\end{tabular}


Özel yetenekli öğrencilerin öğretimi daha etkili hale getirmek için kaliteli eğitim ortamı oluşturarak eğlenceli ve uygulama yapmalarına imkân tanıyacak etkinlik yapmayı düşündükleri görülmektedir. Öğretimi daha etkili yapmak için öğretmen görüşleriyle birlikte öğrenci görüşlerinin de alınması gerektiğini dile getiren özel yetenekliler teftiş unsurunun da etkili öğretimde önemli bir uygulama olduğunu ifade etmişleridir. K2 uygulamalı etkinlikler için sokak çalışmalarını örnek göstermiş, seçmeli derslerin öğrenci seçimlerine göre düzenlenmesi gerektiğinin altını çizmiştir. Yine K3 kaliteli eğitim ortamının oluşması için verimli ders çalışma alanlarının oluşturulmasını "Kütüphanelerdeki imkânlara aktarırdım ve hani genelde bilgisayardan araştırma yapmak yerine kendi böyle ansiklopedilerden araştırmalarını sağlardım. Sınıflardaki imkânları arttırırdım. Sadece bir tahta ve siralar değil de hani yanlarda yine kitapliklar olsun. Ders sirasında öğrenci kalkıp oradan araştırabilsin. Bunu isteyerek sınıflar hazırlardım" cümlesiyle kütüphanelere dikkat çekerek ifade etmiştir. K2, K4 ve K5 öğretimin etkili hale getirilmesi için öğrenci görüşlerinin alınması gerektiğini belirtmiş K4 de "Dersleri öğrencilerin dikkatini çekecek şekilde daha uygulamal hale getirmeye çalışırdım” diyerek uygulamalı çalışmalara değinmiştir. Katılımcıların «Okul yöneticisi öğretimi daha etkili hale getirmek için neler yapabilir?" sorusuna verdiği cevaplardan yapılan bazı alıntılar aşağıda sunulmuştur.

K1 "Okul yöneticisi olsam öğretmenlerin bilgi yeterliliği ile alakalı arada bir sınıfları teftiş ederdim. Müfettişe ihtiyaç duymadan kendi başıma."

K3 “Önceden söylediğim gibi daha kaliteli çalışabilecekleri yerler hazırlardım. Kütüphanelerdeki imkânlara aktarırdım ve hani genelde bilgisayardan araştırma yapmak yerine kendi böyle ansiklopedilerden araştırmalarını sağlardım. Sınıflardaki imkânları arttırırdım. Sadece bir tahta ve sıralar değil de hani yanlarda yine kitaplıklar olsun. Ders sırasında öğrenci kalkıp oradan araştırabilsin. Bunu isteyerek sınıflar hazırlardım."

K4 "Dersleri öğrencilerin dikkatini çekecek şekilde daha uygulamalı hale getirmeye çalışırdım."

\section{Beşinci Alt Probleme İlişkin Bulgular}

Katılımcılara sorulan «Okul yöneticisi olsanız ders programlarını nasıl oluştururdunuz?» sorusuna ilişkin katılımcıların verdiği cevaplar Tablo 5'te 
Tablo 5. Okul Yönetici Olsalar Ders Programlarını Nasıl Oluşturacaklarına İlişkin Katılımcı Görüşleri

\begin{tabular}{ll}
\hline Görüşler & Katılımcı \\
\hline Rehber öğretmene sorarak, & $\mathrm{K} 1$ \\
Bilgili ve tecrübeli öğretmene sorarak, & $\mathrm{K} 1, \mathrm{~K} 2, \mathrm{~K} 14$ \\
Öğrenci merkezli seçmeli dersler, & $\mathrm{K} 2, \mathrm{~K} 3, \mathrm{~K} 4, \mathrm{~K} 5, \mathrm{~K} 7, \mathrm{~K} 11, \mathrm{~K} 12$ \\
Ders dağılımını iyi yaparak, & $\mathrm{K} 3, \mathrm{~K} 6, \mathrm{~K} 8, \mathrm{~K} 9, \mathrm{~K} 10$ \\
\hline
\end{tabular}

Özel yetenekli öğrenciler ders programını öğrenciyi merkeze alan bir yaklaşıma göre düzenleyeceklerini belirtmişlerdir. Ders programında sözel ve sayısal dengesini göz önünde bulunduracaklarını belirten özel yetenekliler program oluştururken tecrübeden yararlanmak gerektiğini de belirtmişledir. K3 ders dağılımında öğrencinin rahatlamasını göz önünde bulundurarak beceri ve yetenek gerektiren dersleri miğfer derslerin arasına serpiştireceğini “Öğrencilerin ders programını beden, resim, müzik gibi dersleri diğer zor derslerin aralarına katarak öğrencileri daha da bir rahat şekilde hani okula gelip daha ders işlemelerini sağlayacak şekilde hazırlardım." cümlesiyle ifade etmiştir. Yine K6 da ders dağılımını sözel ve sayısal ders olarak dikkate alıp dengeli dağılım yapacağını dile getirerek "Ders programlarını hani sayısal, sözel dersleri bir sayısal bir sözel olacak şekilde ayarlardım. Hani sabah mesela fizik dersine girip öğlen direkt matematik böyle fen derslerine girmektense mesela sabah fizik öğlen mesela Türkçe gibi farklı alanlardaki derslerle programı daha da rahatlamaya çalışırdım.” demiştir. K5 “Öğgrencilerin ders programında öğrencinin ne istediği çok önemli. Mesela bazı öğrenciler günün geç saatlerinde daha verimli olabiliyorlar ve günümüzdeki sisteme ne kadar uyar bilmiyorum ama ilk iki dersi seçmeli olarak akşam saatlerine kaydırma gibi bir seçenek sunabilirdim" diyerek ders programlarında öğrencinin tercih ve isteklerinin önemine vurgu yaparak düşüncelerini belirtmiştir. K11 "Ders programlarını öğrencilerin gün içinde çok yorulmamasına ve dersleri verimli geçirmeleri için dengeli bir şekilde hazırlardım" diyerek öğrenci merkezli bir yaklaşımla ders programını dengeli hazırlayarak öğrencinin yorulmamasını sağlayacağını belirtmiştir. K12 de öğrencilerin yetenek ve becerilerine göre kişisel program hazırlayacağını "Okul yöneticisi olsaydım ders programını kişiye göre oluştururdum. Yani eşit ağırlık öğrencisi veya sayısal öğrencisi için kendine ders seçme özelliği sunardım. Tabi bununla beraber sosyal faaliyet de koymayı unutmazdım. Ders programın derslere göre böldüğümüz zaman atıyorum 4 ders varsa 1 sayısal 1 sözel 5 ders varsa bir gün 2 sayısal 1 sözel diğer gün bir sayısal bir sözel şeklinde yani uygun bir dağıtma ile hazırlardım” cümlesiyle ifade etmiştir. Katılımcıların «Okul 
yöneticisi olsanız ders programlarını nasıl oluştururdunuz?» sorusuna verdiği cevaplardan yapılan bazı alıntılar aşağıda sunulmuştur.

K1 "Bu konuda yeterli bilgiye sahip değilim. Büyük ihtimalle okul rehber öğretmeninden veya birtakım bilgili öğretmenlerden yardım alırdım."

K2 "Dediğim gibi seçmeli dersler, okuduğumuz okullarda seçmeli dersler seçiliyor. Bunlara çok önem verirdim. Diğer türlü derslerde öğretmen kadromuza göre ve elimizdeki imkânlara göre belirlemeye çalışırdım."

K3 “Öğrencilerin ders programını beden, resim, müzik gibi dersleri diğer zor derslerin aralarına katarak öğrencileri daha da bir rahat şekilde hani okula gelip daha ders işlemelerini sağlayacak şekilde hazırlardım.”

K4 "Gerçekten öğrencilerin seçtiği dersi, seçmeli dersleri koyardım. Başka dersler koymazdım.”

\section{Sonuç ve Öneri}

Araştırma bulgularına göre özel yetenekli öğrenciler okul yönetimini; disiplin ve denetlemeyi sağlayan bir merci olmanın yanında, okuldaki tüm çalışanların sürece aktif katılımının sağlandığı demokratik bir mekanizma olarak da algılamaktadır. Öğrencilerin okul yönetimini bir karar verme kurumu olarak algıladıkları da dikkat çeken bir başka husustur. Okulu yöneten kişilerin; kim olduğu ve disiplin sağlayıcı olması gerektiği görüşü Demir (2014)'in çalışmasıyla benzerlik göstermektedir. Özel yetenekli öğrenciler okulu, öğrenci, veli ve öğretmen gibi okul yönetiminin tüm bileşenlerinin, uyumlu bir şekilde sürece dâhil edildiği bir kurum olarak görmektedirler. Ayrıca okulu, öğrencilerin istek ve şikâyetleri doğrultusunda ama resmiyetin korunduğu bir zeminde, disiplini sağlayarak yönetmek istediklerini ifade etmişlerdir. Okulda verilen eğitimin daha nitelikli olması için öncelikle öğrencilerin önerilerine yer vereceğini belirten özel yetenekliler eğitim ortamını daha rahat hareket edilebilir ve bilgiye ulaşılabilir şekilde iyileştirmeyi düşündüklerini ifade etmiş, güvenli ve kaliteli okul ortamını sağlamayı düşündüklerini belirtmişlerdir. Özel yetenekli öğrencilerin üzerinde durduğu bir başka husus sokak çalışmaları yaparak derslerin eğlenceli ve uygulamalı hale getirilmesidir. Elde edilen bu bulgu, Akan ve Yarım (2019)'ın ilkokul öğrencilerinin okul ve okul müdürü kavramlarına ilişkin metaforik algılarını inceledikleri çalışmada öğrencilerin okula ilişkin elde ettikleri "bir eğlence ve oyun merkezi" düşüncesiyle örtüşmektedir. Özel yetenekli öğrenciler kontrol mekanizmasını kullanmanın da etkili olacağını belirtmişlerdir. Okul yönetimindeki temel ilkeler konusunda öncelikli olarak disiplin konusuna 
dikkat çeken özel yetenekliler, sosyal ve iletişim becerileri, öğrenci motivasyonunun sağlanması ve öğretmen odaklı bir anlayışın olması gerektiğini ifade etmişlerdir. Bu bulgu Demir (2014)'ün çalışmasıyla örtüşmektedir. Ders programlarının hazırlanmasında, bilgili ve tecrübeli öğretmenin düşüncelerine müracaat edeceklerini belirten özel yetenekliler, seçmeli derslerle ilgili olarak öğrencilerin ilgi ve isteklerine göre düzenleme yapacaklarını ifade etmişlerdir. Ders dağılımının iyi yapılmasını vurgulayan özel yetenekliler, resim, müzik ve beden eğitimi derslerinden daha fazla yararlanmanın önemine dikkat çekmişlerdir. Özel yetenekli öğrencilerin okul yönetim algısının incelendiği bu araştırmanın bulguları; özel yetenekli öğrencilerin eğitiminde önemli bir yeri temsil eden okul yöneticilerinin, okul yönetimine ait ilkelerin ve okuldaki eğitim programının nasıl olması hususunda veri kaynağı olması bakımından ilgili mercilerce değerlendirilebilir. Destek eğitim kurumu olarak, özel yetenekli öğrencilerin örgün eğitime devam ettikleri okul saatleri dışında öğrenim gördükleri BİLSEM' lerde görevlendirilecek okul müdürlerinin seçimlerinde veri kaynağı olarak önerilebilir. Araştırma bulguları özel yetenekli öğrencilerin eğitim ve ihtiyaçlarının neler olduğunun daha iyi anlaşılmasına katkı sağlayabilir.

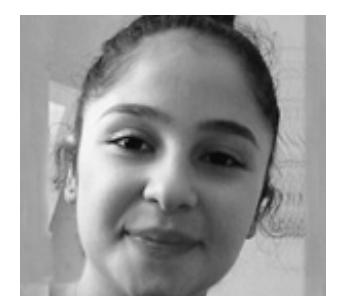

Ece Beril Altın

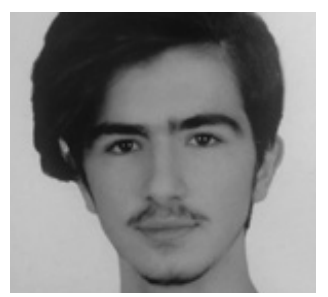

Mert Turgut Toprak

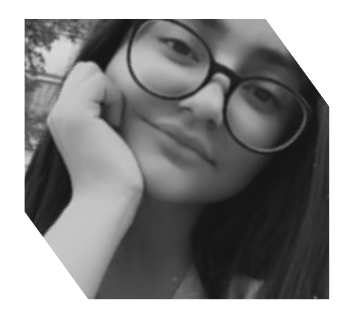

Nehir Korkmaz 


\section{Kaynakça}

Acar, C. (2019). Ortaokullarda görev yapan okul yöneticilerinin mesleki deneyimlerinin incelenmesi: Okul yöneticisi olmanın anlamına yönelik fenemolojik bir çalıșma, (Yayınlanmamıs yüksek lisans tezi). Marmara Üniversitesi, Eḡitim Bilimleri Enstitüsü.

Akan, D. ve Yarım, M. A., (2019), IIlkokul Öğrencilerinin Okul ve Okul Müdürü Kavramlarına Ilișkin Metaforik Algıları, Düzce Üniversitesi Sosyal Bilimler Enstitüsü Dergisi, 9(2), 223-2

Çalık, E. (2008). Illköğretim öğrencilerinin iyimserlik düzeylerinin ve okula ilișkin algılarının incelenmesi. (Yayınlanmamıs yüksek lisans tezi). Ankara Üniversitesi, Eğitim Bilimleri Enstitüsü.

Günes, D. (2014). Üstün Potansiyelli Öğrencilerin Okul Yönetimi Algısının Incelenmesi, (Yayınlanmamıs yüksek lisans tezi). Ankara Üniversitesi, Eḡitim Bilimleri Enstitüsü.

Kesen I, Sundaram D. T., \& Abası K, (2019). Öğretim lideri vs. okul müdürü. İstanbul: SETA Yayınları, https://setav.org/assets/uploads/2019/07/R141.pdf adresinden erișilmiștir.

Levent F (2014). Üstün Yetenekli Çocukları Anlamak. Ankara: Nobel yayınları

MEB, Bilsem Yönergesi, 2016. https://orgm.meb.gov.tr/meb_iys_dosyalar/2016_10/07031350_ bilsem_yonergesi.pdf adresinden erișilmiștir.

Kaya, M. (2020). Okul müdürü kavramına yönelik algıların analizi: Bir katıımcı sözlük fenomeni ekși sözlük örneḡi. Eurasian Journal of Teacher Education, 1 (1), 70 - 81.

Conklin, W., \& Frei, S. (2015). Üstün zekalı ve yetenekliler için ēgitim programının farklılaștırılması. NG Kahveci, Cev.). İstanbul: Özgür.

Yıldırım, A., \& Șimșek, H. (2013). Nitel araștırma yöntemleri. Ankara: Seçkin Yayıncılık. 